\title{
A Cyaphide Transfer Reagent
}

Daniel W. N. Wilson, Stephanie J. Urwin, Eric S. Yang and Jose M. Goicoechea* Department of Chemistry, University of Oxford, Chemistry Research Laboratory, 12 Mansfield Road, Oxford, OX1 3TA, U.K.

E-mail: jose.goicoechea@chem.ox.ac.uk

\begin{abstract}
The cyanide ion plays a key role in a number of industrially relevant chemical processes, such as the extraction of gold and silver from low grade ores. Metal cyanide compounds were arguably some of the earliest coordination complexes studied, and can be traced back to the serendipitous discovery of Prussian blue by Diesbach in 1706 . By contrast, heavier cyanide analogues, such as the cyaphide ion, $\mathrm{C} \equiv \mathrm{P}^{-}$, are virtually unexplored despite the enormous potential of such ions as ligands in coordination compounds and extended solids. This is ultimately due to the lack of a suitable synthesis of cyaphide salts. Herein we report the synthesis and isolation of several magnesium-cyaphido complexes by reduction of ${ }^{i} \mathrm{Pr}_{3} \mathrm{OCP}$ with a magnesium(I) reagent. By analogy with Gringard reagents, these compounds can be used for the incorporation of the cyaphide ion into the coordination sphere of metals using a simple salt-metathesis protocol.
\end{abstract}

\section{Introduction}

Along with the halide ions, cyanide $\left(\mathrm{C} \equiv \mathrm{N}^{-}\right)$is one of the most ubiquitous anions in chemistry. Its salts are routinely used in industrial applications including bulk chemical synthesis, electroplating, metallurgy, tanning, manufacturing of paper and plastics, photography, and as fumigants and insecticides.(1) In organic chemistry, it is an important functional group in nitriles $(\mathrm{R}-\mathrm{C} \equiv \mathrm{N})$ and isonitriles $(\mathrm{R}-\mathrm{N} \equiv \mathrm{C})$, many of which are produced on an industrial scale (e.g. adiponitrile, $\mathrm{NC}\left(\mathrm{CH}_{2}\right)_{4} \mathrm{CN}$, which is used to produce nylon).(2, 3) By contrast, and 
despite the valence isoelectronic relationship between nitrogen and phosphorus, stable phosphorus-containing analogues of cyanides are much rarer; nitrile analogues, so-called phosphaalkynes $(\mathrm{R}-\mathrm{C} \equiv \mathrm{P})$, have been known for almost 40 years and are highly reactive compounds due to the weak nature of $\mathrm{C}-\mathrm{P} \pi$ bonds. $(4,5)$. Isocyanide analogues $(\mathrm{R}-\mathrm{P} \equiv \mathrm{C})$ remain unknown.(6) Unlike cyanide, which forms a multitude of stable salts, the cyaphide ion, $\mathrm{C} \equiv \mathrm{P}^{-}$, cannot be obtained as a simple $\mathrm{A}(\mathrm{CP})$ or $\mathrm{Ae}(\mathrm{CP})_{2}$ salt (where $\mathrm{A}=$ alkali and $\mathrm{Ae}=$ alkaline earth metal). To date, the $\mathrm{C} \equiv \mathrm{P}^{-}$ion has only ever been isolated in the coordination sphere of three metals (platinum, ruthenium and uranium; e.g. trans- $\left[\mathrm{Ru}(\mathrm{dppe})_{2}(\mathrm{H})(\mathrm{CP})\right]$ where dppe $=$ bis(1,2-diphenylphosphino-ethane),(7-12) and an electrophilic borane.(13) While these studies demonstrate that the ion is accessible, the resulting compounds are of limited synthetic utility due to their inertness. Alkali/alkaline-earth metal salts of the cyaphide ion are a more attractive target insomuch as they should allow for the incorporation of $\mathrm{C} \equiv \mathrm{P}^{-}$into novel molecules and solids making use of salt metathesis protocols, a procedure that is well established for cyanides.(14) Herein we show that well-defined alkaline-earth complexes of the cyaphide ion are readily accessible and can be used as anion transfer reagents for the synthesis of novel cyaphido complexes.

\section{$\underline{\text { Results and discussion }}$}

The two-electron chemical reduction of the 2-phosphaethynolate ion, $\mathrm{PCO}^{-},(15)$ to afford a uranium cyaphide complex was recently demonstrated by Meyer.(11) We reasoned that functionalization of $\mathrm{PCO}^{-}$to afford a phosphaethynolato compound $(\mathrm{R}-\mathrm{O}-\mathrm{C} \equiv \mathrm{P})$ would facilitate this reduction step, allowing for the straightforward generation of the cyaphide ion. A major limitation is that oxygen-functionalized phosphaethynolato compounds are rare and largely ionic in character. $\left(11,16^{-21)}\right.$. To date, only one species with significant covalent character has been structurally authenticated.(22) In situ silylation of the $\left.[\mathrm{Na} \text { (dioxane) })_{x}\right] \mathrm{PCO}$ with tris(isopropyl)silyl trifluoromethanesulfonate in non-polar aromatic solvents (benzene or 
toluene) favours silylation at the oxygen atom to afford the kinetic product ${ }^{i} \mathrm{Pr}_{3} \mathrm{SiOCP}$ (Figure 1), which ultimately rearranges to give the $\kappa-\mathrm{P}$ isomer.(23) Reduction of the former species using Jones' magnesium(I) regent $\left[\mathrm{Mg}\left({ }^{\text {Dipp }} \mathrm{NacNac}\right)\right]_{2}(24,25)$ cleanly affords an equimolar mixture of $\left[\mathrm{Mg}\left({ }^{\text {Dipp }} \mathrm{NacNac}\right)(\mathrm{CP})(\right.$ dioxane $\left.)\right](\mathbf{1})$ and $\left[\mathrm{Mg}\left({ }^{\text {Dipp }} \mathrm{NacNac}\right)\left(\mathrm{OSi}^{i} \mathrm{Pr}_{3}\right)(\right.$ dioxane $\left.)\right](\mathbf{2})$ where ${ }^{\text {Dipp }} \mathrm{NacNac}=\mathrm{CH}\left\{\mathrm{C}\left(\mathrm{CH}_{3}\right) \mathrm{N}(\text { Dipp })\right\}_{2}$ and Dipp = 2, 6-di(isopropyl)phenyl (Figure 1). Density functional theory (DFT) calculations predicted this reaction to be exergonic (at $298.15 \mathrm{~K}$ ) by $52.2 \mathrm{kcal} \mathrm{mol}^{-1}$ with an overall energy barrier of $12.5 \mathrm{kcal} \mathrm{mol}^{-1}$. The reaction proceeds via an unobserved dimagnesiated intermediate (a metalla-phosphaalkene) which rearranges by siloxyl group transfer (energy barrier of $4.4 \mathrm{kcal} \mathrm{mol}^{-1}$ ) to afford $\mathbf{1}$ and $\mathbf{2}$ (see supplementary materials for the full computational analysis). Cleavage of the $\mathrm{C}-\mathrm{O}$ bond in the phosphaethynolate ion necessitates a highly oxophilic two-electron reductant and significant steric protection (for example, when the less sterically encumbered magnesium(I) dimer $\left[\mathrm{Mg}\left({ }^{\mathrm{Mes}} \mathrm{NacNac}\right)\right]_{2}(\mathrm{Mes}=$ mesityl $)$ was employed, the analogous reaction gave rise to a mixture of products including cyaphide oligomers).

The magnesium cyaphido complex $\mathbf{1}$, exhibits a resonance in its ${ }^{31} \mathrm{P}\left\{{ }^{1} \mathrm{H}\right\}$ NMR spectrum at $171.4 \mathrm{ppm}$ and a diagnostic singlet resonance in the ${ }^{1} \mathrm{H}$ NMR spectrum corresponding to the ${ }^{\text {Dipp }} \mathrm{NacNac} \gamma$-proton at $4.78 \mathrm{ppm}$. A doublet resonance corresponding to the cyaphide ligand was observed in the ${ }^{13} \mathrm{C}\left\{{ }^{1} \mathrm{H}\right\} \mathrm{NMR}$ spectrum at $271.71 \mathrm{ppm}\left({ }^{1} J_{\mathrm{C}-\mathrm{P}}=33 \mathrm{~Hz}\right)$. Fractional crystallisation of the reaction mixture allowed for the isolation and structural determination of compounds $\mathbf{1}$ and $\mathbf{2}$. 


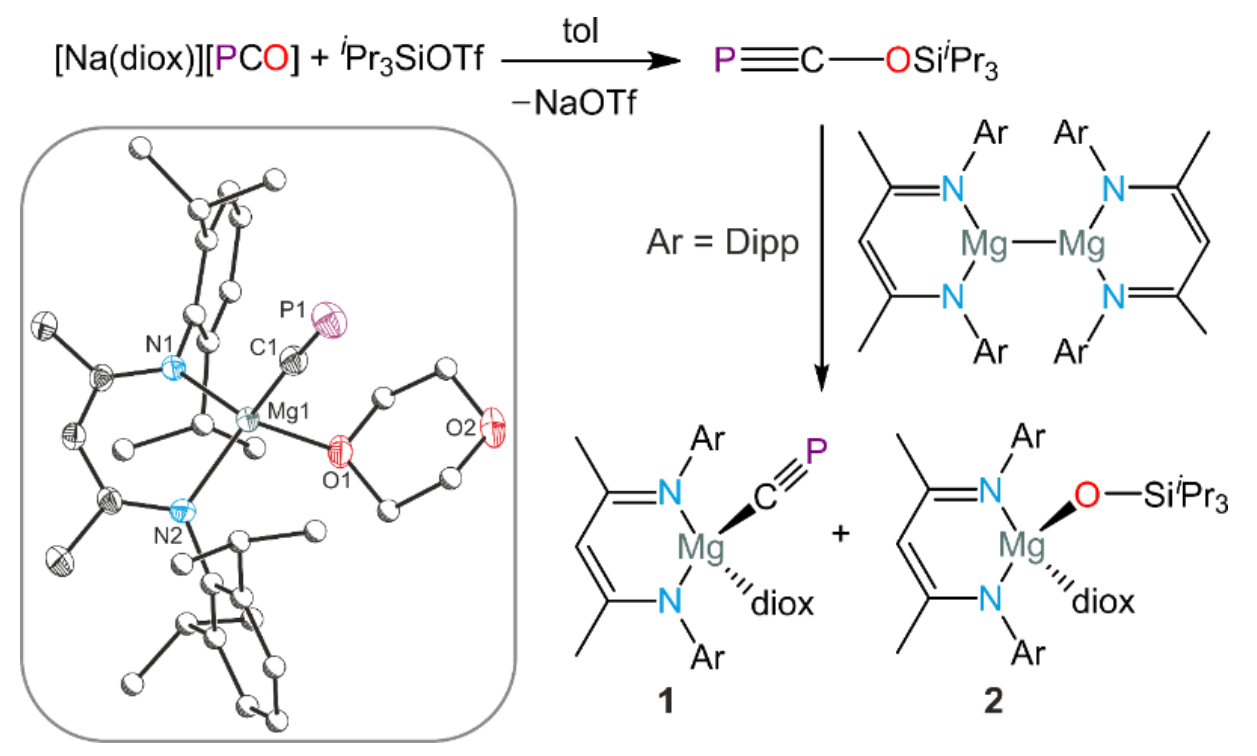

Figure 1. Synthesis of 1 and $\mathbf{2}$ from reduction of ${ }^{i} \operatorname{Pr}_{3} S i O C P$. Inset: Single crystal X-ray structure of 1 (anisotropic displacement ellipsoids set at 50\% probability; hydrogen atoms omitted for clarity; carbon atoms of Dipp and dioxane are pictured as spheres of arbitrary radius).

The crystal structure of $\mathbf{1}$ (Figure 1, inset) revealed a linear arrangement of the $\mathrm{Mg}-\mathrm{C} \equiv \mathrm{P}$ moiety $\left(177.37(15)^{\circ}\right)$, with an $\mathrm{Mg}-\mathrm{C}$ bond length of $2.118(2) \AA$, which is similar to that observed for other related compounds, such as $\left[\mathrm{Mg}\left({ }^{\text {Dipp }} \mathrm{NacNac}\right)\left({ }^{n} \mathrm{Bu}\right)(\mathrm{THF})\right](2.127(2)$ $\AA$ ).(26) The $\mathrm{C}-\mathrm{P}$ bond length in $\mathbf{1}$ is $1.553(2) \AA$, in line with the predicted value for a carbon-phosphorus triple bond (1.54 $\AA$ ) (27), and similar to reported values for other metal cyaphide complexes (cf. 1.573(2) $\AA$ in trans-[Ru(dppe $\left.\left.)_{2}(\mathrm{H})(\mathrm{CP})\right]\right)(9)$. The crystal structure of 2 can be found in the supplementary information.

In situ generated mixtures of $\mathbf{1}$ and $\mathbf{2}$ can be used to transfer the cyaphide ion to metal complexes (vide infra) via a salt metathesis protocol, in a manner reminiscent of Grignard reagents.(28) However, due to the similar solubility of $\mathbf{1}$ and $\mathbf{2}$ in common laboratory 
solvents, the isolation of compositionally pure samples of $\mathbf{1}$ is only possible in low yields (approx. 20\%).

Thus, we sought strategies to modify the solubility of $\mathbf{1}$. Quantitative dioxane displacement was achieved using THF-d $\mathrm{d}_{8}$ to form $\left[\mathrm{Mg}\left({ }^{\text {Dipp }} \mathrm{NacNac}\right)(\mathrm{CP})\left(\mathrm{THF}-\mathrm{d}_{8}\right)\right](\mathbf{3}$; see Figure 2$)$, however this adduct is equally difficult to separate from the siloxy-magnesium side-product. Further, it was observed for both solvent adducts $\mathbf{1}$ and $\mathbf{3}$ that exposure to vacuum initiated decomposition of the target compounds, evidenced by broadening of NMR spectra (SI; Figure S11). We hypothesize that initial cleavage of the Mg-solvent interaction forms the base-free analogue $\left[\mathrm{Mg}\left({ }^{\text {Dipp }} \mathrm{NacNac}\right)(\mathrm{CP})\right]_{x}(4)$, which then rapidly decomposes. Employing dioxane-free $\mathrm{Na}(\mathrm{OCP})$ during the generation of ${ }^{i} \mathrm{Pr}_{3} \mathrm{SiOCP}$ subsequently led to the specific formation of solvent-free analogue 4, evidenced by a ${ }^{31} \mathrm{P}\left\{{ }^{1} \mathrm{H}\right\}$ NMR singlet resonance at $246.7 \mathrm{ppm}$. The solubility of this desolvated analogue is sufficiently lower than $\mathbf{2}$ to facilitate efficient separation by precipitation, however in the solid-state 4 is unstable, decomposing rapidly once isolated (see SI for further details). The structure of $\mathbf{4}$ is currently unknown, but the downfield shifted ${ }^{31} \mathrm{P}$ NMR resonance suggests it is oligomeric; the related solvent-free cyanido-complex, $\left[\mathrm{Mg}\left({ }^{\text {Dipp }} \mathrm{NacNac}\right)(\mathrm{CN})\right]_{3}$, is a cyclic trimer. (29) Addition of dioxane or THF to solutions of $\mathbf{4}$ resulted in the formation of the corresponding solvated adducts $\mathbf{1}$ or $\mathbf{3}$, respectively.

To circumvent problematic cleavage of the coordinated base under vacuum, our attention turned to non-volatile Lewis donors. Addition of excess pyridine or 4-dimethylaminopyridine (DMAP) to a $\mathrm{C}_{6} \mathrm{D}_{6}$ solution of $\mathbf{1}$ did not result in displacement of the dioxane molecule. Addition of $N$-heterocyclic carbenes (NHCs) IMes and I ${ }^{i} \operatorname{Pr}$ (IMes = 1,3-dimesitylimidazol-2ylidene; $I^{i} \operatorname{Pr}=1,3$-diisopropylimidazol-2-ylidene) successfully afforded carbene adducts 
$\left[\mathrm{Mg}\left({ }^{\text {Dipp }} \mathrm{NacNac}\right)(\mathrm{CP})(\mathrm{IMes})\right](5)$ and $\left[\mathrm{Mg}\left({ }^{\text {Dipp }} \mathrm{NacNac}\right)(\mathrm{CP})\left(\mathrm{I}^{i} \mathrm{Pr}\right)\right](\mathbf{6})$, which unlike solvent adducts $\mathbf{1}$ and $\mathbf{3}$ can both be isolated as compositionally pure solids in moderate yields (5: 54\%; 6: 48\%) and can be bottled and stored for several weeks under a nitrogen atmosphere without degradation (Figure 2). No reaction was observed between the NHCs and the siloxy biproduct 2 .
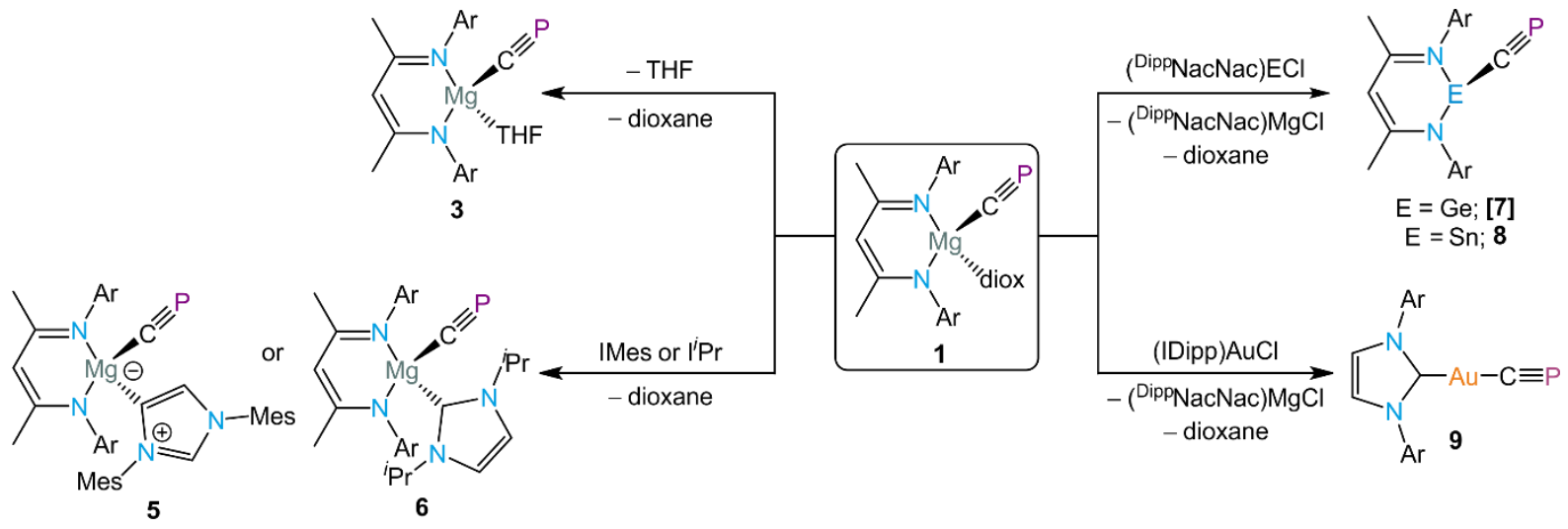

Figure 2. Summary of reactivity of $\mathbf{1}$.

Spectroscopically $\mathbf{5}$ and $\mathbf{6}$ do not differ greatly from compound $\mathbf{1}$ and exhibit comparable NMR shifts [e.g. ${ }^{31} \mathrm{P}\left\{{ }^{1} \mathrm{H}\right\}$ NMR: 162.9 (4); 174.9 ppm (5)]. Both NHC adducts were structurally authenticated by single crystal X-ray diffraction (Figure ) and confirm the expected association of the $\mathrm{NHC}$ with the magnesium metal centre. The $\mathrm{Mg}-\mathrm{C}(5: 2.166(2)$; 6: $2.144(3) \AA$ ) and $\mathrm{C}-\mathrm{P}$ bonds $(5: 1.550(2) ; 6$ : 1.531(3) $\AA$ ) for both compounds are in line with those observed for $\mathbf{1}$. Interestingly, it was found that while the IMes carbene associated with the magnesium metal centre in an "abnormal" fashion (i.e. through the alkenic backbone) the I'Pr carbene adduct coordinates as expected in the solid state, an observation we put down to the increased steric bulk of IMes. However, in solution the $I^{i} \operatorname{Pr}$ moiety of 6 fluctuates between normal and abnormal coordination. The ${ }^{31} \mathrm{P}$ NMR spectrum of $\mathbf{6}$ at room temperature features a particularly broad singlet signal $\left(v_{1 / 2} \approx 224 \mathrm{~Hz}\right)$ which when cooled below $-20{ }^{\circ} \mathrm{C}$ gives rise to two sharper singlet signals at 173.3 (major) and 167.7 (minor) 
ppm (SI, Figure S19). These correspond to the normal and abnormal coordination mode of the $\mathrm{I}^{i} \mathrm{Pr}$ moiety, in good agreement with the DFT calculated chemical shifts (173.9 and 170.9 ppm respectively; SI Table S6). Calculations further indicate that the difference in energy between these two isomers is negligible. 1 does not react with $\mathrm{IMes}^{\mathrm{Me}}$ and $\mathrm{I}^{i} \mathrm{Pr}^{\mathrm{Me}}$, analogous NHCs featuring methylated backbones where abnormal coordination is blocked.
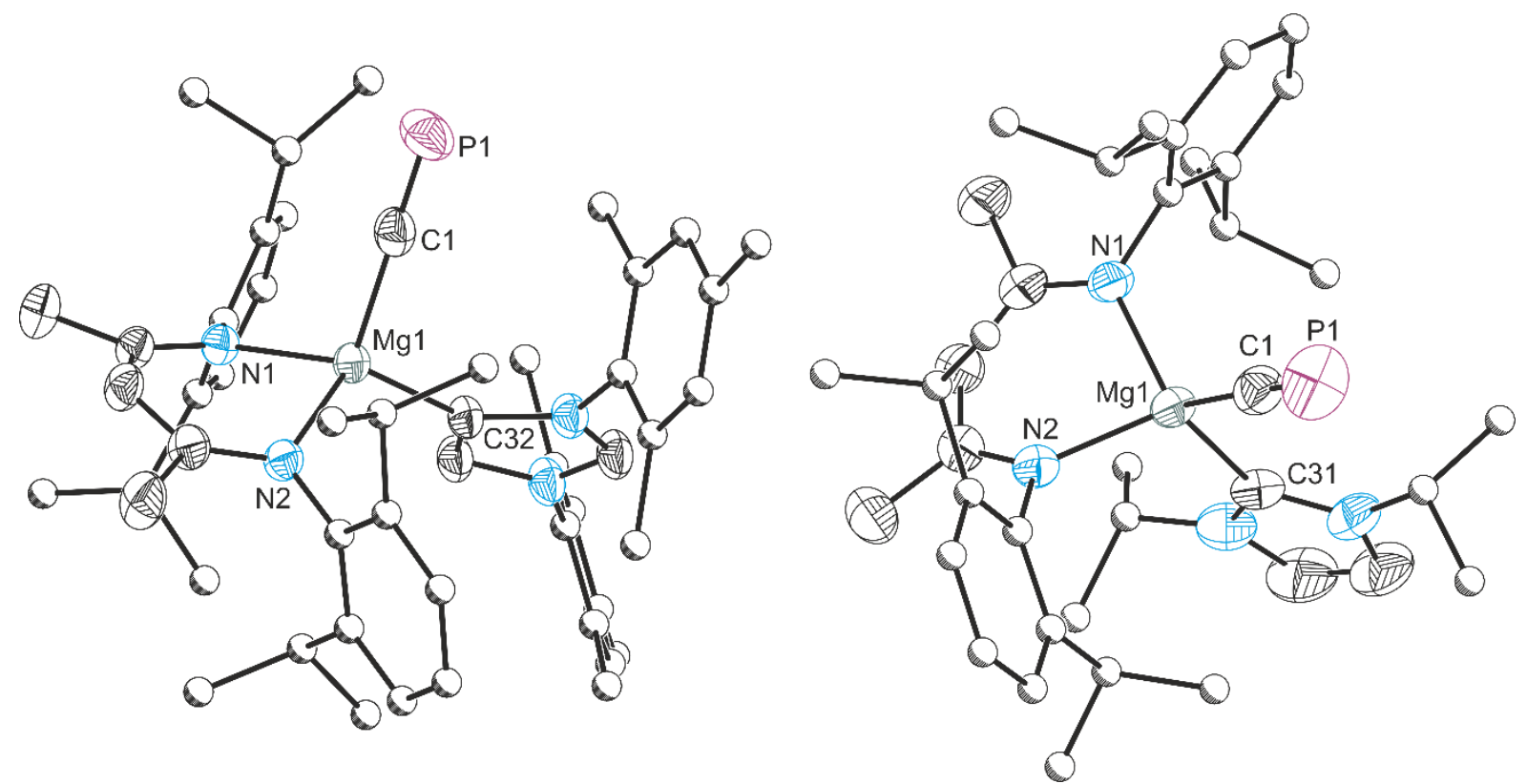

Figure 3. Single crystal X-ray structures of 5 (left) and 6 (right). Anisotropic displacement ellipsoids set at 50\% probability. Hydrogen atoms omitted for clarity. Carbon atoms of Dipp and ${ }^{i} \operatorname{Pr}$ groups are pictured as spheres of arbitrary radius).

IMes adduct 5 co-crystallises with one stoichiometric equivalent of IMes as a co-former, which is also seen in the ${ }^{1} \mathrm{H}$ NMR spectrum of the bulk product. A true co-crystal, no interactions were found between this extra free NHC moiety in either the unit cell or extended structure. Probing further, we calculated no energy payoff for the displacement of the dioxane by IMes (1-3 $\mathrm{kcal} \mathrm{mol}^{-1}$, within error), with neither compound being thermodynamically favoured between -100 to $100^{\circ} \mathrm{C}$. Combining this calculated thermodynamic data with the qualitative observation that co-crystal $\mathbf{5}$ is also isolated when 
one equivalent of IMes is present during formation, we conclude that this co-crystallisation is crucial for its isolation, despite the lower atom economy.

Given the ionic nature of the $\mathrm{Mg}-\mathrm{CP}$ bond in $\mathbf{1}$, we reasoned that salt metathesis reactions between this species and main-group or metal halides would allow for cyaphide group transfer. This hypothesis was probed by addition of chlorotrimethylsilane to a $\mathrm{C}_{6} \mathrm{D}_{6}$ solution of 1 formed in situ. The ${ }^{31} \mathrm{P}\left\{{ }^{1} \mathrm{H}\right\}$ NMR spectrum showed a single resonance at $97.9 \mathrm{ppm}$, corresponding to the known phosphaalkyne $\mathrm{Me}_{3} \mathrm{SiCP} .(30)$ This clean, quantitative transfer of the $\mathrm{CP}^{-}$ion is, to our knowledge, the first instance of such reactivity. Encouraged by this finding, we targeted novel cyaphide metal complexes.

Moving to heavier group 14 elements, addition of [ $\left.\mathrm{Ge}\left({ }^{\text {Dipp }} \mathrm{NacNac}\right) \mathrm{Cl}\right]$ to an in situ generated mixture of $\mathbf{1}$ and $\mathbf{2}$ leads to rapid consumption of $\mathbf{1}$ and a new ${ }^{31} \mathrm{P}\left\{{ }^{1} \mathrm{H}\right\}$ NMR signal at 106.4 ppm (Figure 2). A new singlet signal in the corresponding ${ }^{1} \mathrm{H}$ NMR spectrum at $5.08 \mathrm{ppm}$, within the characteristic region for $\gamma$-H protons, indicates a new ${ }^{\text {Dipp }} \mathrm{NacNac}$ environment. Also evident was that siloxy by-product 2 remained unreacted (SI; Figure S20). Over the course of a few hours, this deep-red solution, presumably containing $\left[\mathrm{Ge}\left({ }^{\mathrm{Dipp}} \mathrm{NacNac}\right)(\mathrm{CP})\right]$ (7), changed to a dark green colour and NMR spectroscopy showed decomposition of the metal-cyaphide complex into multiple phosphorus-containing compounds, a process which was accelerated by any physical manipulation. Reaction of 1 with [ $\left.\mathrm{Sn}\left({ }^{\mathrm{Dipp}} \mathrm{NacNac}\right) \mathrm{Cl}\right]$ led to the formation of $\left[\mathrm{Sn}\left({ }^{\mathrm{Dipp}} \mathrm{NacNac}\right)(\mathrm{CP})\right](\mathbf{8})$, which can be isolated by fractional crystallisation. Cyaphide transfer was first indicated by ${ }^{31} \mathrm{P}\left\{{ }^{1} \mathrm{H}\right\}$ NMR spectroscopy which revealed a new resonance with $\mathrm{P}-\mathrm{Sn}$ coupling satellites at $122.4 \mathrm{ppm}\left({ }^{2} J_{\mathrm{P}-\mathrm{Sn}}=70 \mathrm{~Hz}\right)$, and confirmed in the solid-state structure (Figure 2 ). The $\mathrm{C} \equiv \mathrm{P}$ bond is intact and comparable (1.542(4) $\AA$ ) to those of $\mathbf{1}, \mathbf{5}$ and 6. At $2.216(4) \AA$, the $\mathrm{Sn}-\mathrm{C}$ is relatively long and the $\mathrm{Sn}-\mathrm{C} \equiv \mathrm{P}$ unit is practically 
linear $\left(179.16^{\circ}\right)$. No resonance could be found in the ${ }^{13} \mathrm{C}$ NMR spectrum of $\mathbf{8}$ corresponding to the cyaphide group which we attribute to broadening due to coupling to two adjacent NMR active nuclei. A weak band was observed in the IR spectrum of $\mathbf{8}$ at $1321 \mathrm{~cm}^{-1}$, which is consistent with the predicted value $\left(1327 \mathrm{~cm}^{-1}\right)$, but partially masked by a band arising from a Dipp $\mathrm{C}=\mathrm{C}$ stretching mode.
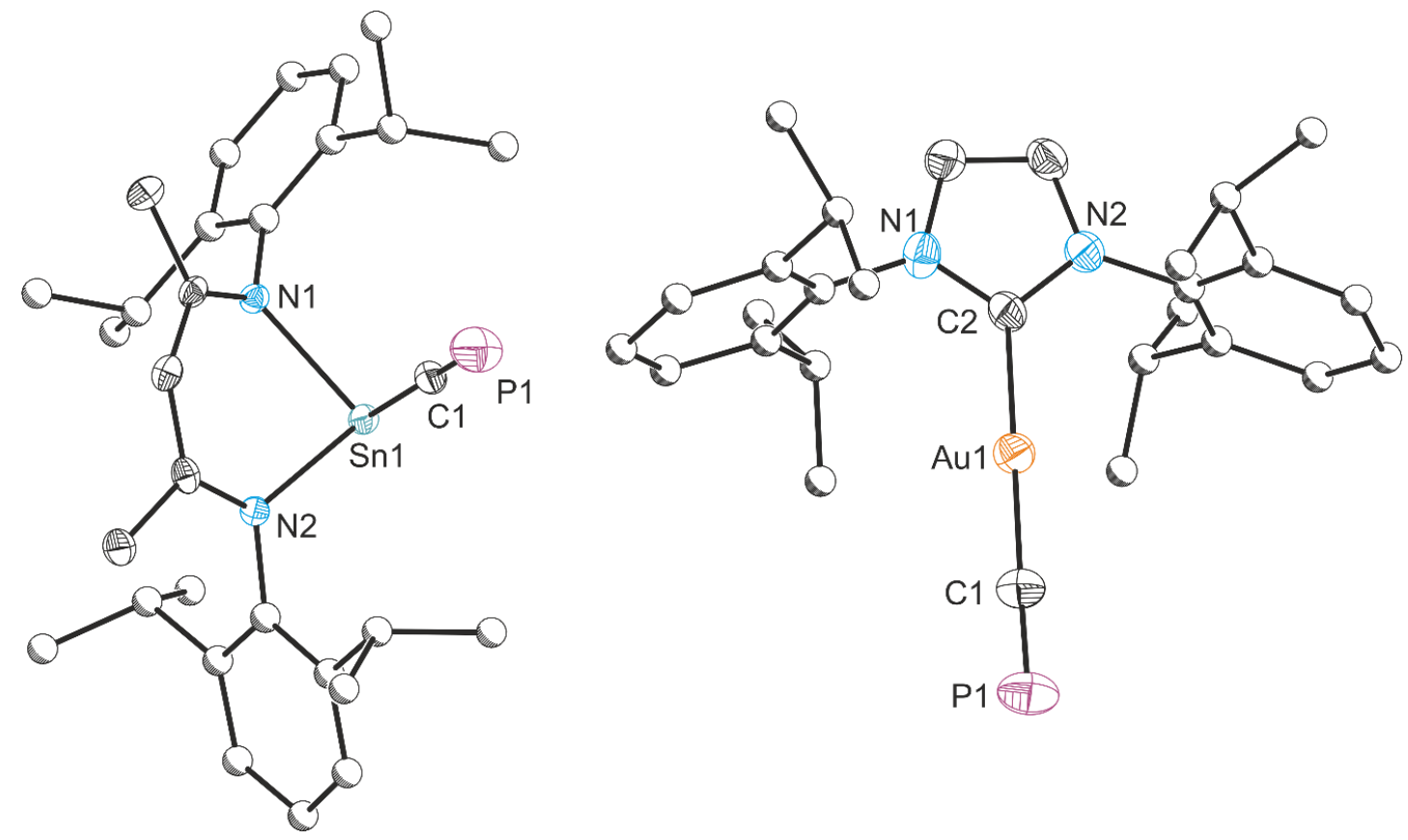

Figure 2. Single crystal X-ray structures of 8 (left) and 9 (right). Anisotropic displacement ellipsoids set at $50 \%$ probability. Hydrogen atoms omitted for clarity.

Having demonstrated inter-metallic cyaphide transfer through halide metathesis, our next target was to prepare a transition metal cyaphide complex. Reaction of an in situ generated mixture of $\mathbf{1}$ and $\mathbf{2}$ with [Au(IDipp)Cl] resulted in the formation of the gold-cyaphido complex $[\mathrm{Au}(\mathrm{IDipp})(\mathrm{CP})](9)$ which exhibits a singlet resonance in its ${ }^{31} \mathrm{P}\left\{{ }^{1} \mathrm{H}\right\} \mathrm{NMR}$ spectrum at $84.1 \mathrm{ppm}$ (Figure 2). This is at a significantly lower frequency than observed for compound 1 (171.4 ppm) and slightly lower than 7 and $\mathbf{8}$ (106.4 and 122.4 ppm), consistent with an increase in the covalent character of the $\mathrm{Au}-\mathrm{CP}$ bond. The ${ }^{13} \mathrm{C}\left\{{ }^{1} \mathrm{H}\right\}$ resonance observed for the cyaphide group in $\mathbf{8}, 247.70 \mathrm{ppm}\left({ }^{1} J_{\mathrm{C}-\mathrm{P}}=6 \mathrm{~Hz}\right)$, is also at a lower frequency 
compared to $\mathbf{1}$ (271.71 ppm). The single crystal X-ray structure of 9 (Figure 4) reveals a linear two-coordinate gold centre $\left(\mathrm{C}-\mathrm{Au}-\mathrm{C}=178.2(2)^{\circ}\right.$; $\left.\mathrm{Au}-\mathrm{C}-\mathrm{P}=178.0(5)^{\circ}\right)$ with $\mathrm{Au}-\mathrm{C}_{\text {carbene }}$ and $\mathrm{Au}-\mathrm{CP}$ distances of 2.034(6) and 1.972(6) $\AA$, respectively. The former of these is slightly elongated compared to that observed in the [(IDipp)AuCl] starting material (1.942(3) $\AA$ ), due to the stronger $\sigma$-donor ability of the cyaphide ion.(31) This distance is more comparable with NHC gold acetylene or cyanido complexes such as $[\mathrm{Au}(\mathrm{IDipp})(\mathrm{C} \equiv \mathrm{CPh})](2.018(7) \AA)$ or $[\mathrm{Au}(\mathrm{IDipp})(\mathrm{CN})](1.985(15) \AA) .(32)$ The $\mathrm{C}-\mathrm{P}$ bond distance in 9 is $1.552(6) \AA$ which is comparable to the other cyaphide complexes discussed thus far (cf. 1.553(2) A for 1). The IR spectrum of compound 9 reveals a band at $1342 \mathrm{~cm}^{-1}$, which is higher than the value reported for trans-[Ru(dppe $\left.)_{2}(\mathrm{H})(\mathrm{CP})\right]\left(1229 \mathrm{~cm}^{-1}\right)$, and thus indicative of little $\pi$-backbonding, however it is worth noting that this vibrational mode is heavily coupled with the $\mathrm{Au}-\mathrm{C}_{\text {carbene }}$ stretch on account of the linear coordination geometry of 9.

\section{Conclusion}

The reductive deoxygenation of ${ }^{i} \mathrm{Pr}_{3} \mathrm{SiOCP}$ offers an efficient route to cyaphide generation at a magnesium centre. This reactive salt is the first example of a cyaphide transfer reagent, allowing for the synthesis of novel metal cyaphido complexes using Grignard-like reactivity. This new reagent will undoubtedly open up new avenues in the coordination chemistry of metal complexes and may ultimately be used for the synthesis of novel extended solids featuring the cyaphide ion such as, for example, Prussian Blue analogues.

\section{Experimental}

General procedures. All reactions and product manipulations were carried out under an inert atmosphere of argon or dinitrogen using standard Schlenk-line or glovebox techniques (MBraun UNIlab glovebox maintained at $<0.1 \mathrm{ppm} \mathrm{H}_{2} \mathrm{O}$ and $<0.1 \mathrm{ppm} \mathrm{O}_{2}$ ). Generation of 
${ }^{i} \mathrm{Pr}_{3} \mathrm{SiOCP}$ was adapted from the previously reported synthesis.(23) $\mathrm{Na}[\mathrm{PCO}$ (dioxane) 5.6$],(33)$ $\left[\mathrm{Mg}\left({ }^{\text {Dipp }} \mathrm{NacNac}\right)\right]_{2},(34)$ IMes,(35) I $\mathrm{Pr},(36)$ [(IDipp)AuCl],(31) [Ge( $\left.\left.{ }^{\text {Dipp }} \mathrm{NacNac}\right) \mathrm{Cl}\right],(37)$ and $\left[\mathrm{Sn}\left({ }^{\mathrm{Dipp}} \mathrm{NacNac}\right) \mathrm{Cl}\right],(37)$ were synthesized according to previously reported synthetic procedures. Triisopropylsilyl trifluoromethanesulfonate (Sigma Aldrich), chlorotrimethylsilane (Sigma Aldrich) were used as received. Hexane (hex; Sigma Aldrich, HPLC grade) and toluene (Sigma Aldrich, HPLC grade) were purified using an MBraun SPS800 solvent system. $\mathrm{C}_{6} \mathrm{D}_{6}$ (Aldrich, $99.5 \%$ ) was dried over $\mathrm{CaH}_{2}$ and degassed prior to use. THF (Sigma Aldrich, HPLC grade) and THF-d 8 (Sigma Aldrich, 99.5\%) were distilled over sodium/benzophenone. All dry solvents were stored under argon in gas-tight ampoules. Additionally, solvents were stored over activated $3 \AA$ molecular sieves.

Characterization techniques. NMR spectra were acquired on Bruker AVIII $500 \mathrm{MHz}\left({ }^{1} \mathrm{H}\right.$ $500 \mathrm{MHz},{ }^{13} \mathrm{C} 126 \mathrm{MHz}$ ) and Bruker AVIII $400 \mathrm{MHz}$ NMR spectrometers $\left({ }^{31} \mathrm{P} 162 \mathrm{MHz}\right)$ at $295 \mathrm{~K}$ unless otherwise stated. ${ }^{1} \mathrm{H}$ and ${ }^{13} \mathrm{C}$ NMR spectra were referenced to residual protic solvent resonance $\left({ }^{1} \mathrm{H}\right.$ NMR $\mathrm{C}_{6} \mathrm{D}_{6}: \delta=7.16 \mathrm{ppm} ;{ }^{13} \mathrm{C}$ NMR $\left.\mathrm{C}_{6} \mathrm{D}_{6}: \delta=188.06 \mathrm{ppm}\right) .{ }^{31} \mathrm{P}$ and ${ }^{119} \mathrm{Sn}$ were externally referenced to an $85 \%$ solution of $\mathrm{H}_{3} \mathrm{PO}_{4}$ in $\mathrm{H}_{2} \mathrm{O}$ and $\mathrm{SnMe}_{4}$, respectively. Elemental analyses were carried out by Elemental Microanalyses Ltd. (Devon, U.K.). Samples (approx. $5 \mathrm{mg}$ ) were submitted in sealed glass vials.

Synthesis of $\left[\mathrm{Mg}\left({ }^{\text {Dipp }} \mathrm{NacNac}\right)(\mathrm{CP})(\right.$ dioxane $\left.)\right](\mathbf{1})$ and $\left[\mathrm{Mg}\left({ }^{\text {Dipp }} \mathrm{NacNac}\right)\left(\mathrm{OSi}^{i} \mathrm{Pr}_{3}\right)(\right.$ dioxane $\left.)\right]$ (2). Inside a glovebox, ${ }^{i} \operatorname{Pr}_{3} \operatorname{SiOTf}(90 \mathrm{mg}, 0.29 \mathrm{mmol})$ was dissolved in toluene (ca. $\left.0.5 \mathrm{~mL}\right)$ and added to a vial containing [Na(dioxane) $\left.)_{5.6}\right] \mathrm{PCO}(167 \mathrm{mg}, 0.29 \mathrm{mmol})$. The resulting suspension was stirred for 4 hours to generate ${ }^{i} \operatorname{Pr}_{3} \operatorname{SiOCP}$, with occasional washing of the walls of the vial to ensure complete consumption of the starting materials. The resulting mixture was filtered through a glass paper filter and the solids washed with a small amount of 
toluene. $\left[\mathrm{Mg}\left({ }^{\text {Dipp }} \mathrm{NacNac}\right)\right]_{2}(195 \mathrm{mg}, 0.22 \mathrm{mmol})$ was added as a solid to the resulting yellow solution, causing it to darken to orange. Reaction completion was confirmed by ${ }^{31} \mathrm{P}\left\{{ }^{1} \mathrm{H}\right\}$ NMR spectroscopy. The solution can be used as an in situ supply of $\mathbf{1}$ with and equimolar amount of 2 also present, a representative ${ }^{1} \mathrm{H}$ NMR of such a solution can be found in Figure S1. Concentration of the solution (taking care to avoid evaporation to dryness) afforded a red oil. The residue was extracted into hexane $(1 \mathrm{~mL})$ and filtered. Cooling the orange solution to $-35^{\circ} \mathrm{C}$ overnight yielded 1 as yellow crystals suitable for X-ray diffraction (29 $\mathrm{mg}, 22 \%$ yield). Further concentrating the solution, or cooling for longer periods, resulted in mixtures of $\mathbf{1}$ and $\mathbf{2}$.

[Mg( $\left.{ }^{\text {Dipp }} N a c N a c\right)(C P)($ dioxane $\left.)\right](1)$ : Anal. Calcd. (\%) for $\mathrm{C}_{34} \mathrm{H}_{49} \mathrm{MgN}_{2} \mathrm{O}_{2} \mathrm{P}: \mathrm{C}, 71.26 ; \mathrm{H}, 8.62$; $\mathrm{N}$, 4.89. Found: 71.35; H, 9.15; N, 4.82. ${ }^{1} \mathrm{H}$ NMR (500 MHz, $\left.\mathrm{C}_{6} \mathrm{D}_{6}\right): \delta(\mathrm{ppm})=7.12-7.06(\mathrm{br}$ m, 6H; Dipp ArH), 4.78 (s, 1H; NacNac $\gamma-\mathrm{H}), 3.34-3.16$ (br m, 12H; Dipp $\mathrm{CH}\left(\mathrm{CH}_{3}\right)_{2}$ and dioxane $\mathrm{CH}_{2}$ ), 1.63 (s, 6H; $\left.\mathrm{NacNac} \mathrm{NCCH}_{3}\right), 1.38\left(\mathrm{~d},{ }^{3} J_{\mathrm{H}-\mathrm{H}}=6.9 \mathrm{~Hz}, 6 \mathrm{H}\right.$; Dipp $\left.\mathrm{CH}\left(\mathrm{CH}_{3}\right)_{2}\right)$, 1.24-1.17 (m, 14H*; Dipp CH(CH3) $\left.)_{2}\right), 0.88\left(\mathrm{~d},{ }^{3} \mathrm{~J}_{\mathrm{H}-\mathrm{H}}=7.9 \mathrm{~Hz}, 6 \mathrm{H} ; \mathrm{Dipp} \mathrm{CH}\left(\mathrm{CH}_{3}\right)_{2}\right.$. [ ${ }^{*}$ Should integrate as $12 \mathrm{H}$, however fluxionality of coordinated dioxane prevents an accurate integration of this region.] ${ }^{13} \mathrm{C}$ NMR $\left(126 \mathrm{MHz}, \mathrm{C}_{6} \mathrm{D}_{6}\right): \delta(\mathrm{ppm})=271.71\left(\mathrm{~d},{ }^{1} J_{\mathrm{C}-\mathrm{P}}=33 \mathrm{~Hz} ; \mathrm{CP}\right), 169.19$ ( $\mathrm{NacNac} \mathrm{NCCH}_{3}$ ), 145.21 (Dipp ArC), 142.81 (Dipp ArC), 142.11 (Dipp ArC), 136.43 (Dipp ArC), 125.63 (Dipp ArC), 124.17 (Dipp ArC), 94.85 (NacNac $\gamma-\mathrm{C}), 67.26\left(\operatorname{Dipp~} C H\left(\mathrm{CH}_{3}\right)_{2}\right)$, $27.98\left(\mathrm{NacNac} \mathrm{NCCH}_{3}\right), 25.98$ (dioxane), 24.67 (Dipp $\left.\mathrm{CH}\left(\mathrm{CH}_{3}\right)_{2}\right), 24.13\left(\operatorname{Dipp~} \mathrm{CH}\left(\mathrm{CH}_{3}\right)_{2}\right)$, 18.98 (unknown impurity). ${ }^{31} \mathrm{P}$ NMR $\left(162 \mathrm{MHz}, \mathrm{C}_{6} \mathrm{D}_{6}\right): \delta(\mathrm{ppm})=250.1^{*}, 171.4$. [* Solvent free $[\mathrm{Mg}] \mathrm{CP}$ approx. 10\%.] IR: The $\mathrm{C} \equiv \mathrm{P}$ bond stretch was calculated to be $1327 \mathrm{~cm}^{-1}$. It was not possible to resolve the peak in the IR spectrum as it is masked by the aromatic $\mathrm{C}-\mathrm{C}$ bond stretches which also appear this region. 


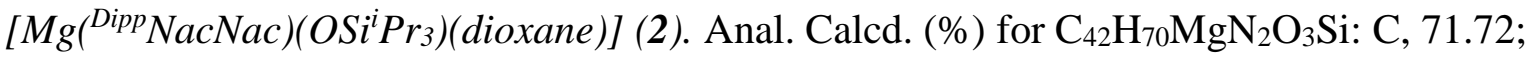
$\mathrm{H}, 10.03 ; \mathrm{N}, 3.98$. Found: $71.99 ; \mathrm{H}, 10.50 ; \mathrm{N}, 4.01 .{ }^{1} \mathrm{H} \mathrm{NMR}\left(500 \mathrm{MHz}, \mathrm{C}_{6} \mathrm{D}_{6}\right): \delta(\mathrm{ppm})=$ 7.15 (m, overlap with $\mathrm{C}_{6} \mathrm{D}_{6}$ prevents integration; Dipp ArH), 4.73 (s, $1 \mathrm{H}$; NacNac $\left.\gamma-\mathrm{H}\right), 3.83$ (s, 6H; dioxane), 3.21 (br sept, ${ }^{3} J_{\mathrm{H}-\mathrm{H}}=6.9 \mathrm{~Hz}, 4 \mathrm{H}$; Dipp $\left.\mathrm{CH}\left(\mathrm{CH}_{3}\right)_{2}\right), 1.59$ (s, 6H; NacNac $\left.\mathrm{NCCH}_{3}\right), 1.38\left(\mathrm{~d},{ }^{3} J_{\mathrm{H}-\mathrm{H}}=6.8 \mathrm{~Hz}, 12 \mathrm{H}\right.$; Dipp CH$\left.\left(\mathrm{CH}_{3}\right)_{2}\right), 1.21\left(\mathrm{~d},{ }^{3} J_{\mathrm{H}-\mathrm{H}}=6.9 \mathrm{~Hz}, 12 \mathrm{H}\right.$; Dipp $\left.\mathrm{CH}\left(\mathrm{CH}_{3}\right)_{2}\right), 0.90$ (two overlapping s, $\left.18 \mathrm{H} ; \mathrm{Si}\left(\mathrm{C}(\mathrm{H}) \mathrm{CH}_{3}\right)_{3}\right) 0.80\left(\mathrm{~m}, 3 \mathrm{H} ; \mathrm{Si}\left(\mathrm{C}\left(\mathrm{H}_{\mathrm{C}} \mathrm{CH}_{3}\right)_{3}\right) .{ }^{13} \mathrm{C}\right.$ NMR (126 MHz, $\left.\mathrm{C}_{6} \mathrm{D}_{6}\right): \delta(\mathrm{ppm})=170.08\left(\mathrm{NacNac}_{\mathrm{NCCH}}\right), 145.28(\mathrm{Dipp}$ ArC), 142.04 (Dipp ArC), 125.72 (Dipp ArC), 124.19 (Dipp ArC), 94.91 (NacNac $\gamma$-C), 67.95 (dioxane), 31.97 (Dipp $\left.\mathrm{CH}\left(\mathrm{CH}_{3}\right)_{2}\right), 28.35\left(\operatorname{Dipp~} \mathrm{CH}\left(\mathrm{CH}_{3}\right)_{2}\right), 25.31\left(\mathrm{NacNac} \mathrm{NCCH}_{3}\right), 24.43(\mathrm{NacNac}$ $\left.\mathrm{NCCH}_{3}\right), 18.96\left(\mathrm{Si}\left(\mathrm{CH}\left(\mathrm{CH}_{3}\right)_{2}\right)_{3}\right), 14.65\left(\mathrm{Si}\left(\mathrm{CH}\left(\mathrm{CH}_{3}\right)_{2}\right)_{3}\right)$.

$\left[M g\left({ }^{\text {Dipp }} \mathrm{NacNac}\right)(\mathrm{CP})\left(\mathrm{THF}-\mathrm{d}_{8}\right)\right](3)$. Generated in situ by addition of THF-d 8 to a solution of 1 in $\mathrm{C}_{6} \mathrm{D}_{6} .{ }^{1} \mathrm{H}$ NMR $\left(500 \mathrm{MHz}, \mathrm{C}_{6} \mathrm{D}_{6}\right) \delta=7.16-7.12$ (m, 6H; Dipp ArH), 4.79 (s, 1H; NacNac $\gamma-\mathrm{H}), 3.53(\mathrm{~s} ; \mathrm{THF}), 3.46\left(\mathrm{sept},{ }^{3} J_{\mathrm{H}-\mathrm{H}}=6.8 \mathrm{~Hz}, 4 \mathrm{H}\right.$; Dipp $\left.\mathrm{CH}\left(\mathrm{CH}_{3}\right)_{2}\right), 3.36$ (s, 8H, free dioxane), $1.64\left(\mathrm{~s}, 6 \mathrm{H} ; \mathrm{NacNac} \mathrm{NCCH}_{3}\right), 1.37\left(\mathrm{~d},{ }^{3} J_{\mathrm{H}-\mathrm{H}}=6.8 \mathrm{~Hz}, 12 \mathrm{H}\right.$; Dipp $\left.\mathrm{CH}\left(\mathrm{CH}_{3}\right)_{2}\right), 1.21\left(\mathrm{~d},{ }^{3} J_{\mathrm{H}-\mathrm{H}}=\right.$ $6.8 \mathrm{~Hz}, 12 \mathrm{H}$; Dipp $\left.\mathrm{CH}\left(\mathrm{CH}_{3}\right)_{2}\right), 0.94-0.84$ (m, 3H; unknown impurity). ${ }^{13} \mathrm{C}$ NMR $(126 \mathrm{MHz}$, $\left.\mathrm{C}_{6} \mathrm{D}_{6}\right) \delta=271.14\left(\mathrm{~d},{ }^{1} J_{\mathrm{C}-\mathrm{P}}=33 \mathrm{~Hz} ; \mathrm{CP}\right), 168.87\left(\mathrm{NacNac} \mathrm{NCCH}_{3}\right), 145.34$ (Dipp ArC), 142.95 (Dipp ArC), 125.49 (Dipp ArC), 124.04 (Dipp ArC), 94.75 (NacNac $\gamma-\mathrm{C}), 67.18$ (free dioxane), 67.02 (THF), $28.05\left(\mathrm{NacNac} \mathrm{NCCH}_{3}\right), 25.77$ (Dipp $\left.\mathrm{CH}\left(\mathrm{CH}_{3}\right)_{2}\right)$, $24.76\left(\operatorname{Dipp~CH}\left(\mathrm{CH}_{3}\right)_{2}\right), 24.61$ (THF), 24.09 (Dipp $\left.\mathrm{CH}\left(\mathrm{CH}_{3}\right)_{2}\right) .{ }^{31} \mathrm{P}$ NMR $\left(162 \mathrm{MHz}, \mathrm{C}_{6} \mathrm{D}_{6}\right) \delta=174.96$.

$\left[\mathrm{Mg}\left({ }^{\mathrm{Dipp}} \mathrm{NacNac}\right)(\mathrm{CP})(\mathrm{IMes})\right]$ (5). 1 (approx. $\left.129.5 \mathrm{mg}, 0.22 \mathrm{mmol}\right)$ was generated in situ, as outlined above. To this, IMes (143.9 $\mathrm{mg}, 0.47 \mathrm{mmol}, 2.1 \mathrm{eq})$ was added as a solution in toluene $(0.5 \mathrm{~mL})$, and the resulting mixture stirred overnight. The volatiles were removed and the residue extracted with pentane $(5 \mathrm{~mL})$. After filtration, the solution was concentrated to 1 
$\mathrm{mL}$ and re-crystallised in a single crop over several days at $-35^{\circ} \mathrm{C}$. The product was isolated as a pale orange solid (134.4 mg, $0.12 \mathrm{mmol}, 54 \%$ yield). Anal. Calcd. (\%) for $\mathrm{C}_{72} \mathrm{H}_{89} \mathrm{MgN}_{6} \mathrm{P}: \mathrm{C}, 79.06 ; \mathrm{H}, 8.20 ; \mathrm{N}, 7.68$. Found: C, 78.10; H, 8.18; N, 7.28. ${ }^{1} \mathrm{H}$ NMR (400 $\left.\mathrm{MHz}, \mathrm{C}_{6} \mathrm{D}_{6}\right): \delta(\mathrm{ppm})=7.22\left(\mathrm{dd},{ }^{3} J_{\mathrm{H}-\mathrm{H}}=7.7,1.6 \mathrm{~Hz}, 2 \mathrm{H} ;\right.$ Dipp ArH $), 7.08\left(\mathrm{t},{ }^{3} J_{\mathrm{H}-\mathrm{H}}=7.6 \mathrm{~Hz}\right.$, 2H; Dipp ArH), 7.05-6.95 (m, 2H; Dipp ArH), 6.79 (s, 4H; free IMes ArH), 6.73 (s, 2H; coord. IMes ArH), 6.52 (s, 2H; coord. IMes ArH), 6.44 (s, 2H; free IMes $\left.\{\mathrm{NCH}\}_{2}\right), 5.86(\mathrm{~d}$, ${ }^{3} J_{\mathrm{H}-\mathrm{H}}=1.4 \mathrm{~Hz}, 1 \mathrm{H}$, coord. IMes $\left.\mathrm{CH}\right), 5.61\left(\mathrm{~d},{ }^{3} J_{\mathrm{H}-\mathrm{H}}=1.5 \mathrm{~Hz}, 1 \mathrm{H}\right.$; coord. IMes $\left.\mathrm{CH}\right), 4.99(\mathrm{~s}$, $2 \mathrm{H} ; \mathrm{NacNac} \gamma-\mathrm{H}), 4.35\left(\mathrm{sept},{ }^{3} J_{\mathrm{H}-\mathrm{H}}=6.8 \mathrm{~Hz}, 2 \mathrm{H}\right.$; Dipp $\left.\mathrm{CH}\left(\mathrm{CH}_{3}\right)_{2}\right), 3.52\left(\mathrm{sept},{ }^{3} J_{\mathrm{H}-\mathrm{H}}=6.9\right.$ $\mathrm{Hz}, 2 \mathrm{H}$; Dipp $\left.\mathrm{CH}\left(\mathrm{CH}_{3}\right)_{2}\right), 2.20$ (s, 3H; free IMes para- $\left.\mathrm{CH}_{3}\right) 2.15$ (s, 6H; $\mathrm{NacNac} \mathrm{NCCH}_{3}$ ), $2.10\left(\mathrm{~s}, 12 \mathrm{H}\right.$; free IMes ortho- $\left.\mathrm{CH}_{3}\right), 1.94\left(\mathrm{~s}, 3 \mathrm{H}\right.$; coord. IMes para- $\left.\mathrm{CH}_{3}\right), 1.78$ (s, 6H; coord. IMes ortho- $\mathrm{CH}_{3}$ ), 1.67 (s, 3H; coord. IMes para- $\left.\mathrm{CH}_{3}\right), 1.57$ (s, 6H; IMes ortho- $\left.\mathrm{CH}_{3}\right), 1.43$ $\left(\mathrm{d},{ }^{3} \mathrm{~J}_{\mathrm{H}-\mathrm{H}}=6.8 \mathrm{~Hz}, 6 \mathrm{H}\right.$; Dipp CH$\left.\left(\mathrm{CH}_{3}\right)_{2}\right), 1.22\left(\mathrm{dd},{ }^{3} J_{\mathrm{H}-\mathrm{H}}=6.8,2.0 \mathrm{~Hz}, 12 \mathrm{H} ;\right.$ Dipp $\left.\mathrm{CH}\left(\mathrm{CH}_{3}\right)_{2}\right), 1.15\left(\mathrm{~d},{ }^{3} \mathrm{~J}_{\mathrm{H}-\mathrm{H}}=6.9 \mathrm{~Hz}, 6 \mathrm{H}\right.$; Dipp CH$\left.\left(\mathrm{CH}_{3}\right)_{2}\right) .{ }^{13} \mathrm{C} \mathrm{NMR}\left(126 \mathrm{MHz}, \mathrm{C}_{6} \mathrm{D}_{6}\right): \delta$ $(\mathrm{ppm})=218.62($ free IMes carbene $C), 167.02\left(\mathrm{NacNac}_{C \mathrm{CH}}\right), 163.31($ coord. IMes $\mathrm{NC}=\mathrm{C}(\mathrm{H}) \mathrm{N}), 147.54$ (Dipp ipso-ArC), 144.57 (coord IMes ipso-ArC), 141.59 (Dipp ipsoArC), 139.29 (coord. IMes para-ArC, 138.84 (free IMes ortho-ArC), 138.73 (Dipp orthoArC), 136.91 (coord. IMes ortho-ArC), 135.42, 135.06 (coord. IMes CH), 130.97 (coord. IMes $C H$ ), 128.88 (coord. IMes meta-ArC), 128.80 (coord. IMes meta-ArC), 128.75 (free IMes meta-ArC), 124.00 (Dipp ArC), 123.76 (Dipp ArC), 122.67 (Dipp ArC), 120.14 (free IMes $\left.\{\mathrm{NCH}\}_{2}\right), 94.70(\mathrm{NacNac} \gamma-\mathrm{C}), 27.80\left(\operatorname{Dipp~} \mathrm{CH}\left(\mathrm{CH}_{3}\right)_{2}\right), 27.35\left(\operatorname{Dipp~} \mathrm{CH}\left(\mathrm{CH}_{3}\right)_{2}\right), 27.19$ (Dipp $\left.\mathrm{CH}\left(\mathrm{CH}_{3}\right)_{2}\right), 24.89\left(\operatorname{Dipp} \mathrm{CH}\left(\mathrm{CH}_{3}\right)_{2}\right), 24.43\left(\operatorname{Dipp~} \mathrm{CH}\left(\mathrm{CH}_{3}\right)_{2}\right), 24.37\left(\operatorname{Dipp~} \mathrm{CH}\left(\mathrm{CH}_{3}\right)_{2}\right)$, 24.31 (coord. IMes ortho- $\mathrm{CH}_{3}$ ), 24.14 (coord. IMes ortho- $\mathrm{CH}_{3}$ ), 20.73 (coord. IMes para$\mathrm{CH}_{3}$ ), 20.67 (free IMes para- $\left.\mathrm{CH}_{3}\right), 20.52\left(\mathrm{NacNac} \mathrm{CCH}_{3}\right), 17.64$ (coord. IMes para- $\mathrm{CH}_{3}$ ), 17.45 (free IMes ortho- $\mathrm{CH}_{3}$ ), 16.47 (coord. IMes para- $\mathrm{CH}_{3}$ ). [No cyaphide carbon observed.] 
${ }^{31} \mathrm{P}\left\{{ }^{1} \mathrm{H}\right\}$ NMR $\left(162 \mathrm{MHz}, \mathrm{C}_{6} \mathrm{D}_{6}\right): \delta(\mathrm{ppm})=162.9 . \mathrm{IR} v_{(\mathrm{CP})}=1316 \mathrm{~cm}^{-1}$ (calculated 1311 $\left.\mathrm{cm}^{-1}\right)$.

Synthesis of $\left[\mathrm{Mg}\left({ }^{\text {Dipp }} \mathrm{NacNac}\right)(\mathrm{CP})\left(I^{\mathrm{i}} \mathrm{Pr}\right)\right](\mathbf{6})$.

1 (approx. $80.2 \mathrm{mg}, 0.14 \mathrm{mmol})$ was generated in situ, as described above. To this, ${ }^{i} \operatorname{Pr}(21.6$ $\mathrm{mg}, 0.14 \mathrm{mmol}, 1.0 \mathrm{eq})$ was added as a solution in toluene $(0.5 \mathrm{~mL})$, and the resulting solution stirred for 2 hours. The volatiles were removed and the residue washed with pentane $(5 \mathrm{~mL})$ and dried. The product was isolated as a beige solid $(41.5 \mathrm{mg}, 0.065 \mathrm{mmol}, 48 \%$ yield). Anal. Calcd. (\%) for $\mathrm{C}_{39} \mathrm{H}_{57} \mathrm{MgN}_{4} \mathrm{P}: \mathrm{C}, 73.51 ; \mathrm{H}, 9.02 ; \mathrm{N}, 8.79$. Found: C, 72.16; H, 9.12; N, 7.59. ${ }^{1} \mathrm{H}$ NMR (400 MHz, $\left.\mathrm{C}_{6} \mathrm{D}_{6}\right): \delta(\mathrm{ppm})=7.30\left(\mathrm{~d},{ }^{3} J_{\mathrm{H}-\mathrm{H}}=6.0 \mathrm{~Hz}, 2 \mathrm{H} ;\right.$ Dipp ArH), 7.19-7.13 (m, overlap with $\mathrm{C}_{6} \mathrm{D}_{6}$ prevents integration), $7.09\left(\mathrm{~d},{ }^{3} J_{\mathrm{H}-\mathrm{H}}=6.0 \mathrm{~Hz}, 2 \mathrm{H}\right.$; Dipp $\mathrm{CH}), 6.23$ (s, 2H; I $\left.\operatorname{Pr}\{\mathrm{NCH}\}_{2}\right), 4.84(\mathrm{~s}, 1 \mathrm{H} ; \gamma-\mathrm{H}), 4.08-3.75$ (br m, 2H; Dipp CH(CH$\left.)_{2}\right)$, 3.25-3.05 (m, 1H, overlap with adjacent signal prevents total integration; I $\left.\mathrm{I} P \mathrm{CH}\left(\mathrm{CH}_{3}\right)_{2}\right)$, 3.08-2.90 (br m, 2H; Dipp CH( $\left.\left(\mathrm{CH}_{3}\right)_{3}\right), 1.77\left(\mathrm{~d},{ }^{3} \mathrm{~J}_{\mathrm{H}-\mathrm{H}}=6.5 \mathrm{~Hz}, 2 \mathrm{H} ; \mathrm{I}^{i} \operatorname{Pr} \mathrm{CH}\left(\mathrm{CH}_{3}\right)_{2}\right), 1.68(\mathrm{~s}$, $6 \mathrm{H}$; $\left.\mathrm{NacNac} \mathrm{NCCH}{ }_{3}\right), 1.34\left(\mathrm{~d},{ }^{3} J_{\mathrm{H}-\mathrm{H}}=6.8 \mathrm{~Hz}, 6 \mathrm{H}\right.$; Dipp $\left.\mathrm{CH}\left(\mathrm{CH}_{3}\right)_{2}\right), 1.14\left(\mathrm{~d},{ }^{3} J_{\mathrm{H}-\mathrm{H}}=6.8 \mathrm{~Hz}\right.$, 6H; Dipp CH(CH3) $), 0.73\left(\mathrm{~d},{ }^{3} \mathrm{~J}_{\mathrm{H}-\mathrm{H}}=6.5 \mathrm{~Hz}, 6 \mathrm{H} ; \mathrm{I}^{i} \mathrm{Pr} \mathrm{CH}\left(\mathrm{CH}_{3}\right)_{2}\right) .{ }^{13} \mathrm{C} \mathrm{NMR}(126 \mathrm{MHz}$, $\left.\mathrm{C}_{6} \mathrm{D}_{6}\right): \delta(\mathrm{ppm})=181.54(\mathrm{I} \operatorname{Pr}$ carbene $C), 167.71\left(\mathrm{NacNac}_{\mathrm{NCCH}}\right), 1.45 .58$ (Dipp ipsoArC) 143.2 (Dipp ortho-ArC), 141.7 (Dipp ortho-ArC), 124.72 (Dipp para-ArC, overlaps with solvent), 124.14 (Dipp meta-ArC), 122.91 (Dipp meta-ArC), 116.26 (broad, I'Pr $\left.\{\mathrm{NCH}\}_{2}\right), 93.49(\mathrm{NacNac} \gamma-\mathrm{C}) 28.42\left(\mathrm{NacNac} C \mathrm{H}\left(\mathrm{CH}_{3}\right)_{2}\right) 28.18\left(\mathrm{NacNac}_{\mathrm{NCCH}}\right) 27.12$ (broad, I'Pr $\left.\mathrm{CH}\left(\mathrm{CH}_{3}\right)_{2}\right), 24.94\left(\mathrm{I}^{\mathrm{i} P r} \mathrm{CH}\left(\mathrm{CH}_{3}\right)_{2}\right) 24.80$ (I $\left.\mathrm{Pr} \mathrm{CH}\left(\mathrm{CH}_{3}\right)_{2}\right), 24.55$ (Dipp $\left.\mathrm{CH}\left(\mathrm{CH}_{3}\right)_{2}\right) 23.91\left(\mathrm{NacNac} \mathrm{NCCH}_{3}\right) 23.87\left(\operatorname{Dipp~} \mathrm{CH}\left(\mathrm{CH}_{3}\right)_{2}\right) 23.51\left(\operatorname{Dipp} \mathrm{CH}\left(\mathrm{CH}_{3}\right)_{2}\right), 19.34$ (broad, I $\left.\mathrm{I} \operatorname{Pr} \mathrm{CH}\left(\mathrm{CH}_{3}\right)_{2}\right) .{ }^{31} \mathrm{P}\left\{{ }^{1} \mathrm{H}\right\}$ NMR $\left(162 \mathrm{MHz}, \mathrm{C}_{6} \mathrm{D}_{6}\right): \delta(\mathrm{ppm})=174.9$ (br s). ${ }^{31} \mathrm{P}\left\{{ }^{1} \mathrm{H}\right\}$ $\operatorname{NMR}\left(162 \mathrm{MHz}, \mathrm{C}_{6} \mathrm{D}_{6}, 253 \mathrm{~K}\right): \delta(\mathrm{ppm})=173.3$ (major) and 167.7 (minor). IR $v_{(\mathrm{CP})}=1325$ $\mathrm{cm}^{-1}$ (calculated $1312 \mathrm{~cm}^{-1}$ ). 
In situ generation of $\left[G e\left({ }^{\text {Dipp }} \mathrm{NacNac}\right)(\mathrm{CP})\right]$ (7). 1 (approx. $70 \mathrm{mg}, 0.15 \mathrm{mmol}$ ) was generated in situ, as outlined above. To this toluene solution, [Ge( $\left.\left.{ }^{\text {Dipp }} \mathrm{NacNac}\right) \mathrm{Cl}\right] \quad(39.5 \mathrm{mg}, 0.075$ mmol) was added as a solid with stirring. NMR spectroscopy showed immediate formation of a new ${ }^{31} \mathrm{P}$-containing compound. Over a few hours, the solution changed colour from red to dark green indicating decomposition. Despite efforts, no pure sample of $\mathbf{7}$ could be isolated. ${ }^{1} \mathrm{H}$ NMR $\left(400 \mathrm{MHz}, \mathrm{C}_{6} \mathrm{D}_{6}\right): \delta(\mathrm{ppm})=5.08(\mathrm{~s}, 1 \mathrm{H} ; \gamma-\mathrm{H}), 4.15\left(\mathrm{sept},{ }^{3} J_{\mathrm{H}-\mathrm{H}}=6.7 \mathrm{~Hz}, 2 \mathrm{H} ;\right.$ Dipp $\left.\left\{\mathrm{CH}\left(\mathrm{CH}_{3}\right)_{2}\right\}\right), 3.42$ (sept; Dipp $\left\{\mathrm{CH}\left(\mathrm{CH}_{3}\right)_{2}\right\}$ overlapping with 2), 1.56 (s; $\mathrm{CCH}_{3}$ overlapping with 2), $1.44\left(\mathrm{~d},{ }^{3} J_{\mathrm{H}-\mathrm{H}}=6.7 \mathrm{~Hz}, 12 \mathrm{H}\right), 1.28\left(\mathrm{~d},{ }^{3} J_{\mathrm{H}-\mathrm{H}}=6.8 \mathrm{~Hz}, 12 \mathrm{H}\right), 1.23\left(\mathrm{~d},{ }^{3} J_{\mathrm{H}-\mathrm{H}}=6.9 \mathrm{~Hz}\right.$, $10 \mathrm{H}$, overlap with 2 prevents precise integration), $1.07\left(\mathrm{~d},{ }^{3} J_{\mathrm{H}-\mathrm{H}}=6.8 \mathrm{~Hz}, 12 \mathrm{H}\right)$. Specific aromatic proton signals could not be identified due to overlap with resonance arising from 2 . ${ }^{31} \mathrm{P}\left\{{ }^{1} \mathrm{H}\right\} \mathrm{NMR}\left(162 \mathrm{MHz}, \mathrm{C}_{6} \mathrm{D}_{6}\right): \delta(\mathrm{ppm})=106.4$.

Synthesis of $\left[\operatorname{Sn}\left({ }^{\text {Dipp }} \mathrm{NacNac}\right)(\mathrm{CP})\right](\mathbf{8}) .1$ (approx. $91.7 \mathrm{mg}, 0.16 \mathrm{mmol}$ ) was generated in situ, as outlined above. To this toluene solution, $\left[\mathrm{Sn}\left({ }^{\text {Dipp }} \mathrm{NacNac}\right) \mathrm{Cl}\right](82.3 \mathrm{mg}, 0.14 \mathrm{mmol})$ was added as a solid with stirring. Over approximately 2 hours, the solution turned burgundy. The solvent was removed and the residue extracted with hexane $(5 \mathrm{~mL})$ and filtered. The solution was concentrated to approx. $1 \mathrm{~mL}$ and cooled to $-35^{\circ} \mathrm{C}$ for 18 hours to form yellow crystals of 8 (28.0 mg, 0.048 mmol, $34 \%$ yield). Anal. Calcd. (\%) for $\mathrm{C}_{30} \mathrm{H}_{41} \mathrm{~N}_{2} \mathrm{SnP}: \mathrm{C}, 62.19 ; \mathrm{H}$, 7.13; N, 4.84. Found: C, 60.87; H, 7.35; N, 4.70. ${ }^{1} \mathrm{H}$ NMR $\left(400 \mathrm{MHz}, \mathrm{C}_{6} \mathrm{D}_{6}\right): \delta(\mathrm{ppm})=$ 7.18-7.09 (m, overlap with residual solvent signal prevents integration), $7.07\left(\mathrm{~d},{ }^{3} J_{\mathrm{H}-\mathrm{H}}=2.1\right.$ Hz, 1H; Dipp CH), 7.06 (d, ${ }^{3} J_{\mathrm{H}-\mathrm{H}}=2.1 \mathrm{~Hz}, 1 \mathrm{H}$; Dipp CH), 5.04 (s, 1H; $\left.\gamma-H\right), 4.12$ (sept, ${ }^{3} J_{\mathrm{H}-\mathrm{H}}=6.7 \mathrm{~Hz}, 2 \mathrm{H}$; Dipp CH$\left.\left(\mathrm{CH}_{3}\right)_{2}\right), 3.28\left(\mathrm{sept},{ }^{3} J_{\mathrm{H}-\mathrm{H}}=6.9 \mathrm{~Hz}, 2 \mathrm{H} ; \operatorname{Dipp~CH}\left(\mathrm{CH}_{3}\right)_{2}\right), 1.60$ $\left(\mathrm{s}, 6 \mathrm{H}, \mathrm{NacNac} \mathrm{NCCH}_{3}\right), 1.44\left(\mathrm{~d},{ }^{3} J_{\mathrm{H}-\mathrm{H}}=6.7 \mathrm{~Hz}, 6 \mathrm{H}\right.$; Dipp $\left.\mathrm{CH}\left(\mathrm{CH}_{3}\right)_{2}\right), 1.31\left(\mathrm{~d},{ }^{3} J_{\mathrm{H}-\mathrm{H}}=6.8\right.$, 6H; Dipp CH(CH3)2), $1.22\left(\mathrm{~d},{ }^{3} J_{\mathrm{H}-\mathrm{H}}=6.9,6 \mathrm{H}\right.$; Dipp $\left.\mathrm{CH}\left(\mathrm{CH}_{3}\right)_{2}\right), 1.11\left(\mathrm{~d},{ }^{3} J_{\mathrm{H}-\mathrm{H}}=6.8 \mathrm{~Hz}, 6 \mathrm{H}\right.$; 
Dipp $\left.\mathrm{CH}\left(\mathrm{CH}_{3}\right)_{2}\right) .{ }^{13} \mathrm{C} \mathrm{NMR}\left(126 \mathrm{MHz}, \mathrm{C}_{6} \mathrm{D}_{6}\right): \delta(\mathrm{ppm})=166.34\left(\mathrm{NacNac} \mathrm{NCCH}_{3}\right), 145.49$

(Dipp ortho-CH), 142.65 (Dipp ortho-CH), 142.31 (Dipp ipso-CH), 136.07 (Dipp ipso-CH), 126.80 (Dipp para-CH), 124.67 (Dipp meta-CH), 123.78 (Dipp meta-CH), 100.59 (NacNac

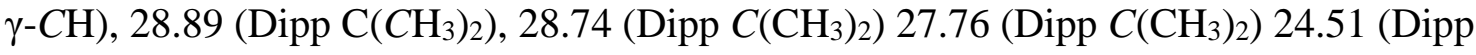
$\left.\mathrm{C}\left(\mathrm{CH}_{3}\right)_{2}\right) 24.15\left(\operatorname{Dipp} \mathrm{C}\left(\mathrm{CH}_{3}\right)_{2}\right) 23.64\left(\mathrm{NacNac} \mathrm{NCCH}_{3}\right) 23.18\left(\operatorname{Dipp~} \mathrm{C}\left(\mathrm{CH}_{3}\right)_{2}\right)$. Cyaphide carbon not observed up to $350 \mathrm{ppm}$, likely due to broadening by the two adjacent nuclei. ${ }^{31} \mathrm{P}\left\{{ }^{1} \mathrm{H}\right\} \mathrm{NMR}\left(162 \mathrm{MHz}, \mathrm{C}_{6} \mathrm{D}_{6}\right) \delta(\mathrm{ppm})=122.4\left({ }^{2} J_{\mathrm{P}-\mathrm{Sn}}=69.8 \mathrm{~Hz}, \mathrm{CP}\right) .{ }^{119} \mathrm{Sn} \mathrm{NMR}(186$ $\left.\mathrm{MHz}, \mathrm{C}_{6} \mathrm{D}_{6}\right): \delta=-245.6$. IR $v_{(\mathrm{CP})}=1321 \mathrm{~cm}^{-1}\left(\right.$ calculated $\left.1327 \mathrm{~cm}^{-1}\right)$.

Synthesis of [Au(IDipp)(CP)] (9). 1 (approx. $106 \mathrm{mg}, 0.22 \mathrm{mmol}$ ) was generated in situ as described above. This toluene solution was added dropwise to a stirred solution of [Au(IDipp)Cl] $(75.0 \mathrm{mg}, 0.12 \mathrm{mmol})$ in toluene $(1 \mathrm{~mL})$. The reaction was stirred for 2 hours and filtered through a glass paper filter. The solvent was removed to dryness and the yellow solids washed with hexane $(3 \times 2 \mathrm{~mL})$ [NB: The hexane fraction can be collected and concentrated to afford 2]. The resulting white solid was taken into toluene ( $2 \mathrm{~mL})$ and filtered to remove remaining $\left[\mathrm{Mg}\left({ }^{\text {Dipp }} \mathrm{NacNac}\right) \mathrm{Cl}(\right.$ dioxane $\left.)\right]$. Crystals were obtained by slow diffusion of hexane into a concentrated toluene solution at $-35^{\circ} \mathrm{C}(41 \mathrm{mg}, 54 \%$ yield). Anal. Calcd. (\%) for $\mathrm{C}_{28} \mathrm{H}_{36} \mathrm{AuN}_{2} \mathrm{P}: \mathrm{C}, 53.51 ; \mathrm{H}, 5.77 ; \mathrm{N}, 4.46$. Found: 54.14; H, 5.87; N, 4.32. ${ }^{1} \mathrm{H}$ NMR (500 $\left.\mathrm{MHz}, \mathrm{C}_{6} \mathrm{D}_{6}\right): \delta(\mathrm{ppm})=7.15(\mathrm{~m}, 2 \mathrm{H}$; Dipp para-CH$), 7.01\left(\mathrm{~d},{ }^{3} \mathrm{~J}_{\mathrm{H}-\mathrm{H}}=7.7 \mathrm{~Hz}, 4 \mathrm{H} ;\right.$ Dipp

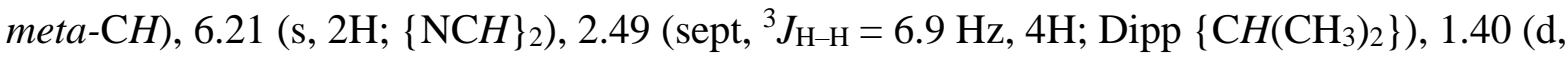
$\left.{ }^{3} J_{\mathrm{H}-\mathrm{H}}=6.9 \mathrm{~Hz}, 12 \mathrm{H} ; \operatorname{Dipp}\left\{\mathrm{CH}\left(\mathrm{CH}_{3}\right)_{2}\right\}\right), 1.04\left(\mathrm{~d}, 12 \mathrm{H},{ }^{3} J_{\mathrm{H}-\mathrm{H}}=6.9 \mathrm{~Hz} ; \operatorname{Dipp}\left\{\mathrm{CH}\left(\mathrm{CH}_{3}\right)_{2}\right\}\right)$, $0.30\left(\mathrm{~s},<1 \mathrm{H}\right.$; unknown impurity). ${ }^{13} \mathrm{C}$ NMR $\left(126 \mathrm{MHz}, \mathrm{C}_{6} \mathrm{D}_{6}\right): \delta(\mathrm{ppm})=247.70\left(\mathrm{~d},{ }^{1} J_{\mathrm{C}-\mathrm{P}}=6\right.$ $\mathrm{Hz} ; \mathrm{CP}), 193.02\left(\mathrm{~d},{ }^{3} J_{\mathrm{C}-\mathrm{P}}=6 \mathrm{~Hz}\right.$; carbene C), $145.29\left(\{\mathrm{NCH}\}_{2}\right), 144.72(\mathrm{ArC}), 134.02(\mathrm{ArC})$, 130.49 (ArC), 123.94 (ArC), 122.57 (ArC), 28.65 (Dipp $\left.\left\{\mathrm{CH}\left(\mathrm{CH}_{3}\right)_{2}\right\}\right), 24.45$ (Dipp 
$\left.\left\{\mathrm{CH}\left(\mathrm{CH}_{3}\right)_{2}\right\}\right), 23.53\left(\operatorname{Dipp}\left\{\mathrm{CH}\left(\mathrm{CH}_{3}\right)_{2}\right\}\right) .{ }^{31} \mathrm{P}\left\{{ }^{1} \mathrm{H}\right\} \mathrm{NMR}\left(162 \mathrm{MHz}, \mathrm{C}_{6} \mathrm{D}_{6}\right): \delta(\mathrm{ppm})=84.1$.

IR $v_{(\mathrm{CP})}=1342 \mathrm{~cm}^{-1}\left(\right.$ calculated $\left.1332 \mathrm{~cm}^{-1}\right)$.

\section{$\underline{\text { Associated content }}$}

Crystallographic data for the structures reported in this article have been deposited at the Cambridge Crystallographic Data Centre, under deposition nos. CCDC 2078056 (1), 2078057 (2), 2078058 (4), 2078059 (5·IMes), 2078060 (6), 2078061 (8) and 2078062 (9). Copies of the data can be obtained free of charge from the CCDC via www.ccdc.cam.ac.uk/structures. Apart from the datasets mentioned, all other data supporting the findings of this study are available within the Article and Supplementary Information.

\section{Funding Sources}

EPSRC and OxICFM CDT for financial support of this re-search (DWNW: DTA studentship; SJU: EP/T010681/1; ESY: EP/S023828/1).

\section{Acknowledgement}

We thank the University of Oxford, the EPSRC and OxICFM CDT for financial support of this research (DWNW: DTA studentship; SJU: EP/T010681/1; ESY: EP/S023828/1). Dr. Stefan Mitzinger is acknowledged for optimising the conditions for the formation of ${ }^{i} \mathrm{Pr}_{3} \mathrm{SiOCP}$. The University of Oxford is also acknowledged for access to Chemical Crystallography facilities.

\section{Author Contributions}

JMG and DWNW conceived of the project. DWNW synthesised and characterised compounds 1-4 and 9, and contributed to X-ray crystallographic studies. SJU synthesised and characterised compounds 5-8. ESY completed all DFT and mechanistic calculations. 
JMG directed the work and contributed to X-ray crystallographic studies. JMG and SJU cowrote the manuscript. All authors commented on and edited the manuscript.

\section{Competing interests}

The authors declare no competing interests.

\section{$\underline{\text { References }}$}

(1) Gail, E., Gos, S., Kulzer, R., Loroesch, J., Sauer, M., Kellens, R., Reddy, J., Steier, N. \& Haspenpusch, W. “Cyano compounds, inorganic” in: Ullmann's Encyclopedia of Industrial Chemistry (Wiley-VCH, Weinheim, 2011)

(2) Pollak, P., Romeder, G., Hagedorn, F. \& Gelbke, H.-P. “Nitriles” in Ullmann's Encyclopedia of Industrial Chemistry (Wiley-VCH, Weinheim, 2000).

(3) Palmer, R.J. "Polyamides, Plastics" in Encyclopedia of Polymer Science and Technology, (Wiley, Hoboken, 2001).

(4) Becker, G., Gresser, G. \& Uhl, W. Acyl- and alkylidenephosphines, XV [1] 2,2dimethylpropvlidynephosphine, a stable compound with a phosphorus atom of coordination Number 1. Z. Naturforsch. B 36, 16-19 (1981).

(5) Regitz, M. Phosphaalkynes: New Building Blocks in Synthetic Chemistry, Chem. Rev. 90, 191-213 (1990).

(6) Weber, L. The quest for isophosphaalkynes (isophosphocyanides) $\mathrm{C} \equiv \mathrm{P}-\mathrm{R}-\mathrm{Still}$ an elusive class of compounds. Eur. J. Inorg. Chem. 2003, 1843-1856 (2003).

(7) Jun, H., Young, Jr., V. G. \& Angelici, R. J. Phosphorus analogue $\left(\mathrm{C} \equiv \mathrm{P}^{-}\right)$of a bridging cyanide $\left(\mathrm{C} \equiv \mathrm{N}^{-}\right)$ligand: Synthesis and structure of $(\mathrm{Cl})\left(\mathrm{PEt}_{3}\right)_{2} \mathrm{Pt}(\mu-\mathrm{C} \equiv \mathrm{P}) \mathrm{Pt}\left(\mathrm{PEt}_{3}\right)_{2} . J . A m$. Chem. Soc. 114, 10064-10065 (1992).

(8) Jun, H. \& Angelici, R. J. Bridging Cyaphide $\left(\mathrm{C} \mathrm{P}^{-}\right)$and Bridging Aryl Isocyaphide 
$(\mathrm{C} \equiv \mathrm{P}-\mathrm{R})$ Ligands: Synthesis and Characterization of $(\mathrm{X})\left(\mathrm{PEt}_{3}\right)_{2} \mathrm{Pt}(\mu-\mathrm{C}=\mathrm{P}) \mathrm{Pt}\left(\mathrm{PEt}_{3}\right)_{2}$ and $(\mathrm{X})\left(\mathrm{PEt}_{3}\right) \mathrm{Pt}(\mu-\mathrm{C}=\mathrm{P}-\mathrm{R}) \mathrm{Pt}\left(\mathrm{PEt}_{3}\right)_{2}(\mathrm{X})(\mathrm{X}=\mathrm{Cl}, \mathrm{Br} ; \mathrm{R}=$ 2,4,6-tri-tert butylphenyl $)$.

Organometallics 13, 2454-2460 (1994).

(9) Cordaro, J. G., Stein, D., Rüegger, H. \& Grützmacher, H. Making the true "CP” ligand. Angew. Chem. Int. Ed. 45, 6159-6162 (2006).

(10) Trathen, N., Leech, M. C., Crossley, I. R., Greenacre, V. K. \& Roe, S. M. Synthesis and electronic structure of the first cyaphide-alkynyl complexes. Dalton Trans. 43, 9004-9007 (2014).

(11) Hoerger, C. J., Heinemann, F. W., Louyriac, E., Maron, L., Grützmacher, H. \& Meyer, K. Formation of a uranium-bound $\eta^{1}$-cyaphide $\left(\mathrm{CP}^{-}\right)$ligand via activation and $\mathrm{C}-\mathrm{O}$ bond cleavage of phosphaethynolate $\left(\mathrm{OCP}^{-}\right)$. Organometallics 36, 4351-4354 (2017).

(12) Levis, M. C., Pearce, K. G. \& Crossley, I. R. Controlled Reactivity of Terminal Cyaphide Complexes: Isolation of the 5-Coordinate $\left[\mathrm{Ru}(\mathrm{dppe})_{2}(\mathrm{C} \equiv \mathrm{P})\right]^{+}$. Inorg. Chem. 58, 14800-14807 (2019).

(13) Finz, M., Bernhardt, E., Willner, H. \& Lehmann, C. W. $\left[\left(\mathrm{CF}_{3}\right)_{3} \mathrm{BCP}\right]^{-}$and $\left[\left(\mathrm{CF}_{3}\right)_{3} \mathrm{BCAs}\right]^{-}$: Thermally stable phosphaethynyl and arsaethynyl complexes. Angew. Chem. Int. Ed. 43, 4160-4163 (2004).

(14) A. M. Nauth, T. Opatz, Non-toxic cyanide sources and cyanating agents. Org. Biomol. Chem. 17, 11-23 (2019).

(15) For a recent review see: Goicoechea, J. M \& Grützmacher, H. The chemistry of the 2phosphaethynolate anion. Angew. Chem. Int. Ed. 57, 16968-16994 (2018).

(16) Westerhausen, M., Schneiderbauer, S., Piotrowski, H., Suter, M. \& Nöth, H. Synthesis of alkaline earth metal bis(2-phosphaethynolates). J. Organomet. Chem. 643-644, 189-193 (2002). 
(17) Camp, C., Settineri, N., Lefevre, J., Jupp, A. R., Goicoechea, J. M., Maron, L., Arnold, J. Uranium and thorium complexes of the phosphaethynolate ion. Chem. Sci. 6, 6379-6384 (2015).

(18) Gilliard, R. J., Heift, D., Benko, Z., Keiser, J. M., Rheingold, A. L., Grützmacher, H., Protasiewicz, J. D. An isolable magnesium diphosphaethynolate complex. Dalton Trans. 47, 666-669 (2018).

(19) Bestgen, S., Chen, Q., Rees, N. \& Goicoechea, J. M. Synthesis and reactivity of rareearth metal phosphaethynolates. Dalton Trans. 47, 13016-13024 (2018).

(20) Grant, L. N., Pinter, B., Manor, B. C., Grützmacher, H. \& Mindiola, D. J. A ScandiumStabilized Diisophosphaethynolate Ligand: [OCPPCO ${ }^{4-}$. Angew. Chem. Int. Ed. 57, $1049-$ 1052 (2018).

(21) Mei, Y., Borger, J. E., Wu, D. J. \& Grützmacher, H. Salen supported Al-O-C $\equiv P$ and Ga-P=C=O complexes. Dalton Trans. 48, 4370-4374 (2019).

(22) Wilson, D. W. N., Hinz, A. \& Goicoechea, J. M. An isolable phosphaethynolatoborane and its reactivity. Angew. Chem. Int. Ed. 57, 2188-2193 (2018).

(23) Heift, D., Benkö, Z. \& Grützmacher, H. Is the phosphaethynolate anion, (OCP)- an ambident nucleophile? A spectroscopic and computational study. Dalton Trans. 43, 59205928 (2014).

(24) Green, S. P., Jones, C. \& Stasch, A. Stable Magnesium(I) Compounds with Mg-Mg Bonds. Science 318, 1754-1757 (2007).

(25) Jones, C. Dimeric magnesium(I) $\beta$-diketiminates: a new class of quasi-universal reducing agent. Nat. Rev. Chem. 1, 0059 (2017).

(26) Chisholm, M. H., Choojun, K., Galluccia, J. C. \& Wambua, P. M. Chemistry of magnesium alkyls supported by 1,5,9-trimesityldipyrromethene and 2-[(2,6- 
diisopropylphenyl)amino]-4-[(2,6-diisopropylphenyl)imino]pent-2-ene. A comparative study. Chem. Sci. 3, 3445-3457 (2012).

(27) Pyykkö, P., Riedel, S. \& Patzschke, M. Triple-Bond Covalent Radii. Chem. Eur. J. 11, $3511-3520(2005)$.

(28) Rappoport, Z. \& Marek I., Eds. The Chemistry of Organomagnesium Compounds; (Wiley-VCH, Weinheim, 2008).

(29) Ma, M., Stasch, A. \& Jones, C. Magnesium(I) Dimers as Reagents for the Reductive Coupling of Isonitriles and Nitriles. Chem. Eur. J. 18, 10669-10676 (2012).

(30) Appel, R. \& Westerhaus, A. $\left(\mathrm{CH}_{3}\right)_{3} \mathrm{Si}-\mathrm{C} \equiv \mathrm{P}$, ein silylfunktionelles phospha-alkin. Tetrahedron Lett. 22, 2159-2160 (1981).

(31) Fructos, M. R., Belderrain, T. R., de Frémont, P., Scott, N. M., Nolan, S. P., DíazRequejo, M. M. \& Pérez, P. J. A Gold Catalyst for Carbene-Transfer Reactions from Ethyl Diazoacetate, Angew. Chem. Int. Ed. 44, 5284-5288 (2005).

(32) Gaillard, S., Slawin, A. M. Z. \& Nolan, S. P. A N-heterocyclic carbene gold hydroxide complex: a golden synthon. Chem. Commun. 46, 2742-2744 (2010).

(33) Heift, D., Benko, Z. \& Grützmacher, H. Coulomb repulsion versus cycloaddition: formation of anionic four-membered rings from sodium phosphaethynolate, $\mathrm{Na}(\mathrm{OCP})$. Dalton Trans. 43, 831-840 (2014).

(34) Hicks, J., Juckel, M., Paparo, A., Dange, D. \& Jones, C. Multigram Syntheses of Magnesium(I) Compounds Using Alkali Metal Halide Supported Alkali Metals as Dispersible Reducing Agents. Organometallics 37, 4810-4813 (2018).

(35) Arduengo III, A. J., Dias, H. V. R., Harlow, R. L. \& Kline, M. Electronic stabilization of nucleophilic carbenes. J. Am. Chem. Soc. 114, 5530-5534 (1992).

(36) Burling, S., Paine, B. M., Nama, D., Brown, V. S., Mahon, M. F., Prior, T. J., Pregosin, P. S., Whittlesey, M. K. \& Williams, J. M. J. C-H Activation Reactions of Ruthenium N- 
Heterocyclic Carbene Complexes: Application in a Catalytic Tandem Reaction Involving C-C Bond Formation from Alcohols. J. Am. Chem. Soc. 129, 1987-1995 (2007).

(37) Ding, Y., Roesky, H. W., Noltemeyer, M., Schmidt, H. \& Power, P. P. Synthesis and Structures of Monomeric Divalent Germanium and Tin Compounds Containing a Bulky Diketiminato Ligand. Organometallics 20, 1190-1194 (2001). 